\title{
Ant community richness and composition across a gradient from Eucalyptus plantations to secondary Atlantic Forest
}

\author{
Silvia Sayuri Suguituru ${ }^{1}$, Rogério Rosa Silva², Débora Rodrigues de Souza ${ }^{1}$, \\ Catarina de Bortoli Munhae ${ }^{3}$ \& Maria Santina de Castro Morini ${ }^{1,4}$
}

${ }^{1}$ Núcleo de Ciências Ambientais, Laboratório de Mirmecologia, Universidade de Mogi das Cruzes - UMC, Av. Dr. Cândido Xavier de Almeida e Souza, n. 200, CEP 08701-970, Mogi das Cruzes, SP, Brasil

${ }^{2}$ Museu de Zoologia, Universidade de São Paulo - USP,

Av. Nazaré, n. 481, CEP 04263-000, São Paulo, SP, Brasil

${ }^{3}$ Centro de Estudos de Insetos Sociais, Universidade Estadual Paulista - UNESP,

Av. 24 A, n. 1515, CEP 13506-900, São Paulo, SP, Brasil

${ }^{4}$ Corresponding author: Maria Santina de Castro Morini, e-mail: morini@umc.br

SUGUITURU, S.S., SILVA, R.R., SOUZA, D.R., MUNHAE, C.B. \& MORINI, M.S.C. Ant community richness and composition across a gradient from Eucalyptus plantations to secondary Atlantic Forest. Biota Neotrop. 11(1): http://www.biotaneotropica.org.br/v11n1/en/abstract?inventory+bn00811012011.

\begin{abstract}
Secondary forests and exotic tree plantations are expanding across tropical landscapes. However, our current understanding of the value of these human-dominated forest landscapes for invertebrate biodiversity conservation is still very poor. In this paper, we use the leaf-litter ant fauna to assess invertebrate diversity in one commercially managed Eucalyptus plantation (four years old), two abandoned plantations of different regeneration ages (16 and 31 years), and one neighboring secondary Atlantic Forest in Southeastern Brazil. There was a clear gradient in species richness from the secondary forest to the managed Eucalyptus plantation; richness and diversity peaked in secondary forest and in the older regenerating Eucalyptus plantation. Significantly more species were recorded in secondary forest samples than in Eucalyptus plantations, but Eucalyptus plantations had a similar level of richness. Furthermore, a non-metric multidimensional scaling analysis revealed clear differences in species composition between the younger managed Eucalyptus plantation (understory absent) and habitats with sub-developed or developed understory. Eucalyptus plantations were characterized by an assemblage of widespread, generalist species very different from those known to occur in core forest habitats of southeastern Brazil. Our results indicate that while older regenerating Eucalyptus plantations can provide habitat to facilitate the persistence of generalist ant species, it is unlikely to conserve most of the primary forest species, such as specialized predators, Dacetini predators, and nomadic species.
\end{abstract}

Keywords: Formicidae, habitat modification, eucalipt plantations, diversity.

SUGUITURU, S.S., SILVA, R.R., SOUZA, D.R., MUNHAE, C.B. \& MORINI, M.S.C. Riqueza e composição das comunidades de formigas em um gradiente de plantio de Eucalyptus a Mata Atlântica secundária. Biota Neotrop. 11(1): http://www.biotaneotropica.org.br/v11n1/pt/abstract?inventory+bn00811012011.

Resumo: As florestas secundárias e plantações de espécies exóticas estão se expandindo nas paisagens tropicais. No entanto, nossa compreensão sobre o valor destas florestas para a conservação da biodiversidade de invertebrados ainda é incipiente. Neste trabalho, usamos a fauna de formigas de serapilheira para avaliar a diversidade desses insetos entre três florestas de Eucalyptus, sendo uma comercial (quatro anos de idade) e duas abandonadas em diferentes idades de regeneração (16 e 31 anos) e uma área de Mata Atlântica secundária. A riqueza total foi mais alta na floresta secundária e nos plantios de Eucalyptus abandonados há mais tempo. A densidade de espécies na floresta secundária foi significativamente maior quando comparado as plantações de Eucalyptus, mas não difere entre eucaliptais; análise de ordenação revelou diferenças na composição de espécies entre as plantações de Eucalyptus com subbosque ausente e com subbosque desenvolvido ou em desenvolvimento. Ainda, foi constatada uma sobreposição acentuada entre amostras de serapilheira das florestas de eucaliptos abandonadas há mais tempo e a floresta secundária. Em geral, plantações de eucalipto foram caracterizadas pela presença de espécies generalistas e de ampla distribuição. Nossos resultados indicam que embora o subbosque de plantações de eucaliptos com maior idade de regeneração suporte um conjunto relativamente alto de espécies generalistas de formigas, é improvável que eucaliptais conservem a maioria das espécies de florestas primárias, especialmente predadores especializados, Dacetini e espécies nômades.

Palavras-chave: Formicidae, modificação de hábitats, plantações de eucalipto, diversidade. 


\section{Introduction}

The Atlantic Forest once covering more than a million squared kilometers, was reduced to $12 \%$ of the original cover (Ribeiro et al. 2009) and the total protected area is only 1.62\% (Laurance 2009). The Atlantic Forest is recognized as one of the most highly threatened biodiversity hotspot of the world (SOS Mata Atlântica 1998, Myers et al. 2000), with high number of endemic species (Martini et al. 2007, Carnaval et al. 2009, Metzger et al. 2009).

In the Southeastern Brazil extensive Atlantic Forest areas had been replaced by managed tree plantations. The exotic Eucalyptus trees were introduced in Southern Brazil in 1868 to increase the production of railroad ties (Lima 1993). Presently, they are used mainly in the pulpwood industry and for energy production in ironworks. Plantations have increased rapidly within Brazil, where the coverage of Eucalyptus planted for the pulpwood industry has increased 17-fold since 1980 (Sociedade... 2006). It is estimated that Brazil has the largest land area of Eucalyptus plantations in the world; in Southeastern Brazil alone they occupy about 611,500 ha (Kronka 2005).The value for wildlife of extensive monocultures, as well as of areas of native regeneration, is surprisingly poorly understood (Kanowski et al. 2005). Our current knowledge is insufficient to predict whether these habitats could help to conserve tropical forest species for the future (Gardner et al. 2007, 2008). However, they are likely to become a dominant feature in the tropical forest landscapes (Wright \& Muller-Landau 2006). Most studies have been restricted to a few well-studied taxa (birds and mammals) in tropical regions and landscapes dominated by sites with similar regeneration ages since abandonment (Machado \& Lamas 1996, Barlow et al. 2007b). However, studies along gradients of landscape modification could be important for understanding response patterns of the invertebrate fauna to forest modification (Summerville \& Crist 2002, PinkusRendón et al. 2006), and the use of ecological indicators to assessment of forest disturbance has been suggested (McGeoch \& Chown 1998, Uehara-Prado et al. 2009).

Ants are routinely used as indicators of ecological change and ecosystem dynamics (Underwood \& Fisher 2006) because they are ubiquitous, highly abundant, diverse, and respond to ecosystem disturbance. Ants are important predators, competitors, and mutualists in most terrestrial habitats (Hölldobler \& Wilson 1990), with effects on soil structure (McKey et al. 2010) and process which affect the flow of energy and material in ecosystems (Folgarait 1998).

In most habitats, plant communities determine the physical structure of the environment and have considerable influence on the distribution of animal species at a range of spatial scales (Tews et al. 2004, Lassau et al. 2005). Habitat structure is an important determinant of tropical ant community composition (Lassau \& Hochuli 2004), and there is a strong association between ant species richness and composition and a more complex habitat structure in regenerating forests (Dunn 2004). The wildlife value of plantations can be highly dependent on levels of understory regeneration (Stallings 1991, Mitra \& Sheldon 1993). Older unmanaged Eucalyptus plantations with dense understories in Southeastern Brazil can support relatively high numbers of bird species (Willis 2003). Studies that found a high diversity in tree plantations show that the latter are associated with mature stands that are floristically similar to natural forests (Duran \& Kattan 2005).

In the present study, we compared the leaf-litter ant diversity in human-modified Atlantic Forest areas in Southeastern Brazil. We contrasted the leaf-litter ant diversity among naturally regenerated Atlantic Forest and abandoned Eucalyptus plantations. The abandoned plantation forests represent a gradient of Atlantic Forest regeneration and are composed of different tree species and different types of understory vegetation. Our hypothesis is that the ant community richness and composition differs between forests across a gradient from Eucalyptus plantations to secondary Atlantic Forest. We expected that 1) the species richness of leaf-litter ant fauna is linked to structure of the understory vegetation at each site, and 2) the similarity in species composition between secondary forest and eucalipt plantations increases with increase regeneration age.

\section{Material and Methods}

\section{Study area}

The study sites are located in the Parque das Neblinas (23 $3^{\circ} 44^{\prime} 51^{\prime \prime} \mathrm{S}$ and $46^{\circ} 08^{\prime} 39^{\prime}$ W), Bertioga county, State of São Paulo, Southeastern Brazil. Four adjacent study sites of similar size (40 ha) were chosen, close to primary Atlantic Forest:

- A secondary Atlantic Forest area (SF): The understory is developed, characterized by herbaceous plants, shrubs, and tree canopies $>1.5 \mathrm{~m}$.

- Four year-old managed Eucalyptus grandis (Hill ex Maiden) plantation (Eg4): The plantation is characterized by the absence of an understory. The native understory vegetation is periodically cleared or suppressed, either by manual removal or herbicidal treatment.

- Sixteen year-old Eucalyptus saligna Smith plantation (Es16): This area was commercially managed and was abandoned in 1988. The understory is under-developed, characterized by herbaceous plants, shrubs, and trees $>1 \mathrm{~m}$;

- Thirty-one year-old Eucalytpus grandis (Hill ex Maiden) plantation (Eg31): This plantation was commercially managed and was abandoned in 1973. The understory is developed, characterized by herbaceous plants, shrubs and tree canopies $>1 \mathrm{~m}$.

\section{Sampling design}

In each area, a 1,200 $\mathrm{m}$ long line transect was selected for the ant survey. Transects started $500 \mathrm{~m}$ from the forest edge and contained 25 points, each $50 \mathrm{~m}$ apart. At each point, two samples were collected, one $25 \mathrm{~m}$ to the left and one $25 \mathrm{~m}$ to the right of the point. At each of the 50 sample points, a $1 \mathrm{~m}^{2}$ plot (quadrat) was established on the ground. All leaf-litter inside the plot was collected, sifted and put into a bag. The sifted material was brought to the field-laboratory and its fauna was extracted using mini-Winklers for 48 hours (Agosti \& Alonso 2000, Bestelmeyer et al. 2000). Surveys were carried out during the rainy season and after rainy periods to enhance the likelihood of collecting cryptic and hypogaeic ant species.

The material was initially identified to genera and then to morphospecies. Identification to species level was carried out by comparison with the Formicidae collection of the Museu de Zoologia da Universidade de São Paulo (MZUSP), and with pertinent literature. Classification follows (Bolton et al. 2006). Vouchers were deposited at the Universidade de Mogi das Cruzes (SP) and MZUSP.

We used leaf-litter depth as a surrogate for resource availability within the quadrats. In each sampling unit, the litter depth was measured at the center of quadrat by vertically inserting a ruler marked in $0.5-\mathrm{cm}$ increments into the topsoil.

\section{Data analysis}

In the analyses, we treated each sample as a statistical independent replicate. All samples come from points at least $50 \mathrm{~m}$ apart; as the home range of most leaf-litter ant species covers less than a few meters, the samples were considered independent. Species richness was defined as the number of ant species occurring in each litter 
sample. Matrices of species by sites quadrats were constructed, and filled with occurrence data (presence $=1$, absence $=0$ ). One occurrence was defined as the presence of one species in one $1 \mathrm{~m}^{2}$, no matter how many individuals were present.

We considered leaf-litter depth within the quadrats as a surrogate for resource availability for leaf-litter ant fauna. Leaf-litter depth is an appropriate measure because leaf-litter provides suitable places for nesting and is the resource base for litter-dwelling ants. We tested the hypothesis that understory age increases ant species richness by using the Kruskal-Wallis test, followed by multiple comparison test adjusted appropriately using "kruskalmc" function in pgirmess package (Giraudoux 2010). We evaluated the relationship between leaf-litter and species richness at each site using General Linear Models (GLM), with leaf-litter depth as an explanatory variable and species richness within quadrats as a response variable. Poisson errors were corrected for overdispersion (Crawley 2002).

Patterns of species richness among different forest types were compared using sample-based rarefaction curves constructed using EstimateS version 7.5.2 (Colwell 2005). Comparisons among areas were standardized by the number of occurrence, because we were interested in patterns of species richness and not in species density (Gotelli \& Colwell 2001). Estimated species richness was calculated for each habitat using Estimates version 7.5.2, using the mean of the three commonly employed incidence-based estimators for ant biodiversity studies (Chao2, Jack1 and Bootstrap2).

Ordination analysis (non-metric multidimensional scaling) based on a Bray-Curtis dissimilarity matrix, using presence-absence data to compare patterns of species composition and community structure, were implemented in the vegan package (Oksanen et al. 2009).

\section{Results}

We recorded a total of 37,486 leaf-litter ants in 200 samples from all habitats. These were assigned to 135 species and morphospecies representing 48 genera and 11 subfamilies. A total of 87 species were found in the secondary Atlantic Forest, 79 within one E. grandis plantation (31 years, developed understory), 76 in the E. saligna plantation (16 years, sub-developed understory) and 61 in the other E. grandis plantation (4 years, without understory) (Table 1). We identified $32(23.5 \%), 8(5.9 \%), 14(17 \%)$ and $9(6.62 \%)$ species, respectively, that were unique to each habitat. Thirty-two species (24\%) were common to all habitats.

The nMDS ordination show distinct sample clusters, in special, the immature eucalipt plantation $(\mathrm{Eg} 4)$. However, there were a large amount of overlap in sample composition among secondary forest and older eucalypt plantations (Es16 and Eg31; Figure 1) mean that a number of secondary forest species can be found in areas of eucalypt plantations with an understory of native shrubs. Species generally considered rare and cryptic occurred in the studied areas irrespective to habitat; these were: Adelomyrmex sp. (secondary forest), Amblyopone armigera Mayr (Eg4 and Eg31), A. elongata (Santschi) (secondary forest), Brachymyrmex micromegas Emery (secondary forest), Cylindromyrmex brasiliensis Emery (Es16), Basiceros sp.2 (Eg4 and Eg31), Phalacromyrmex fugax Kempf (Eg31), and Typhlomyrmex sp.2 (secondary forest and Eg31) (Table 1).

The accumulated richness curves did not approximate the level of the asymptote (Figure 2), indicating that the sample size was not large enough to sample the expected species richness. The mean of the three estimators (Chao2, Jack 1 and Bootstrap) yielded an extrapolated maximum of 108.04 species for the secondary forest, 93.61 for the E. grandis plantation (31 years), 117.41 for the E. saligna plantation (16 years), and 71.26 species for the other E. grandis plantation (4 years).
There was no relationship between leaf-litter depth and ant species richness in any of the study sites (SF: $t$-value $=-0.355$, $\mathrm{p}=0.724 ;$ Eg31: $\mathrm{t}$-value $=-0.381, \mathrm{p}=0.705 ;$ Es16: $\mathrm{t}$-value $=0.254$, $\mathrm{p}=0.800 ;$ Eg 4 : $\mathrm{t}$-value $=1.039 ; \mathrm{p}=0.304)$. We did not find significant differences in leaf-litter depth among sites (Kruskal-Wallis $=4.1024$, $\mathrm{df}=3$, p-value $=0.2506$ ). However, there was a significant effect of understory structure on leaf-litter ant species richness at the quadrat level (Kruskal-Wallis $=42.8354, \mathrm{df}=3$, p-value $=0.000$ ). Significantly more species were recorded in secondary forest than in Eucalyptus plantations ( $\mathrm{p}<0.01)$, but Eucalyptus plantations had a similar level of richness $(\mathrm{p}>0.01)$.

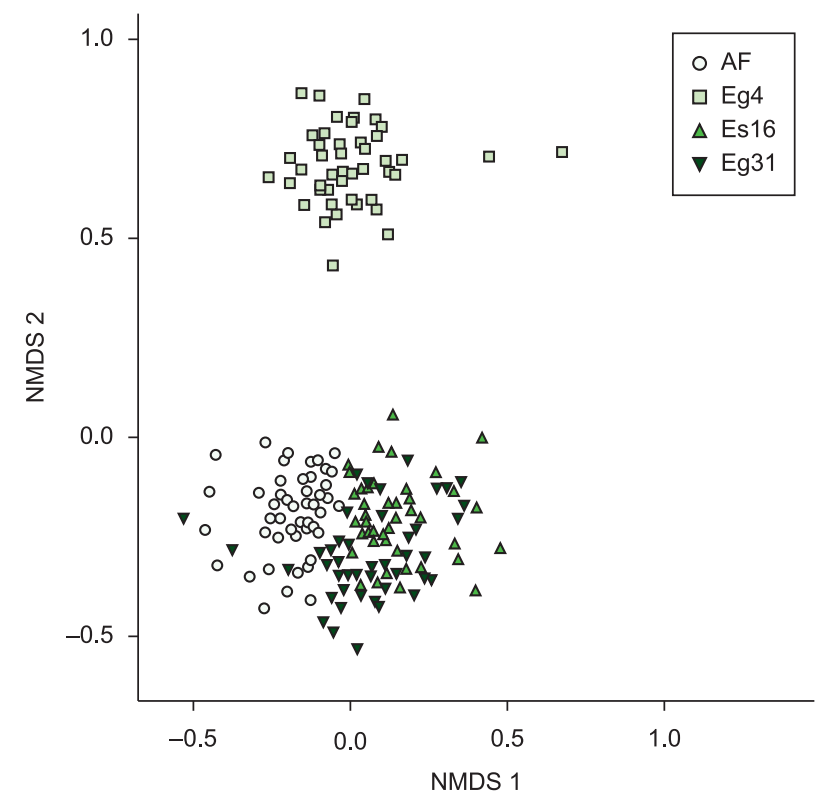

Figure 1. Non-metric multidimensional scaling (NMDS) ordination for leaf-litter ant communities sampled in four forests. Ordination analyses are based on presence-absence dissimilarity matrices (Bray-Curtis). SF: secondary forest; Eg4: 4 year-old Eucalyptus grandis; Es16: 16 year-old Eucalyptus saligna; and Eg31: 31 year-old Eucalyptus grandis.

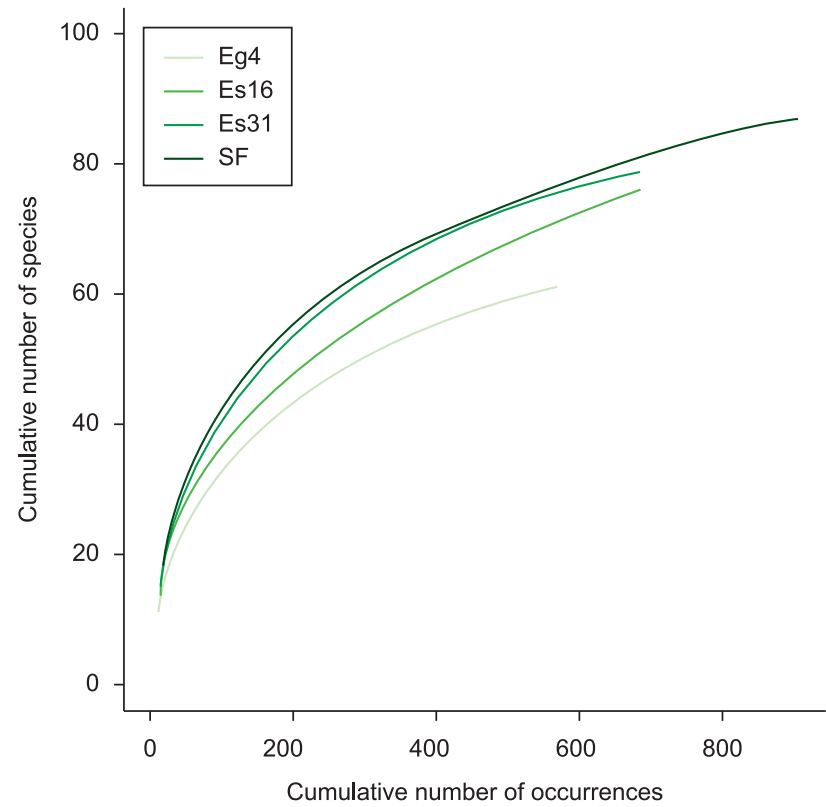

Figure 2. Species rarefaction curves of the number of species plotted against the number of occurrences of leaf-litter ant species. SF: secondary forest; Eg4: 4 year-old Eucalyptus grandis; Es16: 16 year-old Eucalyptus saligna; and Eg31: 31 year-old Eucalyptus grandis. 
Suguituru, S.S. et al.

Table 1. Number of occurrences of each ant species collected in $50 \mathrm{~m}^{2}$ samples of leaf-litter in the studied areas. Eg4: Eucalyptus grandis 4 years old; Es16: Eucalyptus saligna (16 years old); Eg31: Eucalyptus grandis (31 years old); and SF: secondary forest.

\section{Subfamily/species}

Amblyoponinae

Amblyopone armigera Mayr, 1887

Amblypone elongata Santschi, 1912

Prionopelta antillana Forel, 1909

Cerapachinae

Cylindromyrmex brasiliensis Emery, 1901

Dolichoderinae

Azteca $\mathrm{sp} .2$

Linepithema neotropicum Wild, 2007

Linepithema iniquum (Mayr, 1870)

Tapinoma melanocephalum (Fabricius, 1793)

Ecitoninae

Eciton burchelli (Westwood, 1842)

Eciton quadriglume (Haliday, 1836)

Labidus praedator (Smith F., 1858)

Ectatomminae

Ectatomma edentatum Roger, 1863

Gnamptogenys continua (Mayr, 1887)

G. reichenspergeri (Santschi, 1929)

Gnamptogenys striatula Mayr, 1884

Gnamptogenys sp.5

Formicinae

Camponotus (Tanaemyrmex) sp.

Camponotus sp.6

Camponotus sp.8

Camponotus sp.10

Brachymyrmex heeri Forel, 1874

Brachymyrmex incisus Forel, 1912

Brachymyrmex luederwaldti Santschi, 1929

Brachymyrmex micromegas Emery, 1923

Brachymyrmex pictus Mayr, 1887

Myrmelachista catharinae Mayr, 1887

Myrmelachista ruszkii Forel, 1903

Paratrechina fulva (Mayr, 1862)

Heteroponerinae

Heteroponera dentinodis (Mayr, 1887)

Heteroponera dolo (Roger, 1961)

Heteroponera mayri Kempf, 1962

Myrmicinae

Acromyrmex niger (F. Smith, 1858)

Acromyrmex rugosus rochai Forel, 1904

Acromyrmex sp.7

Apterostigma sp.1

Cyphomyrmex auritus Mayr, 1887

Cyphomyrmex strigatus Mayr, 1887

Mycetosoritis sp.1

Myrmicocrypta sp.1

Trachymyrmex (gr.septentrionales) sp.4

\section{Eg4}

Es16

Eg31

SF

$\begin{array}{llll}2 & - & 6 & - \\ - & - & - & 5 \\ 3 & - & 3 & 5\end{array}$

$\begin{array}{ll}- & 1\end{array}$

17

35

10

18

$-$

$-$

$$
-
$$

$$
1
$$$$
1
$$

2

2

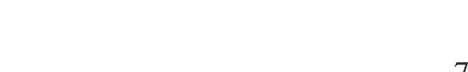

$-$

1

11

$\begin{array}{rrrr}11 & 2 & 6 & - \\ - & 1 & 1 & 6 \\ - & - & 2 & 1 \\ 5 & 19 & 18 & 11 \\ - & - & - & 1\end{array}$

$-$

$-$

1

$-$

$-$

$-$

-

-

36

41

$\begin{array}{rrrr}2 & 1 & 1 & 1 \\ - & - & 1 & - \\ - & 11 & 21 & 25\end{array}$

\begin{tabular}{rrrr}
10 & 3 & 4 & 8 \\
2 & - & - & - \\
1 & - & - & - \\
4 & 3 & 3 & 4 \\
- & 1 & - & - \\
- & - & - & 1 \\
18 & 34 & 24 & 23 \\
- & - & - & 5 \\
- & 1 & 5 & - \\
\hline
\end{tabular}


Table 1. Continued...

\begin{tabular}{|c|c|c|c|c|}
\hline Subfamily/species & Eg4 & Es16 & Eg31 & SF \\
\hline Trachymyrmex oetkeri Forel, 1908 & 2 & - & 1 & - \\
\hline Basiceros disciger (Brown \& Kempf, 1960) & - & - & - & 5 \\
\hline Basiceros sp. 2 & 2 & - & 1 & - \\
\hline Basiceros rugiferum Mayr, 1887 & 24 & 3 & 4 & 29 \\
\hline Basiceros stenognathum (Brown \& Kempf,1960) & 3 & 6 & 19 & 33 \\
\hline Wasmannia sp.3 & 42 & 38 & 6 & 19 \\
\hline Procryptocerus sp. pr. schmalzi & - & 1 & - & - \\
\hline Crematogaster (Orthocrema) sp. 1 & - & 3 & - & 6 \\
\hline Crematogaster sp.5 & - & - & 1 & - \\
\hline Crematogaster sp. 8 & 1 & - & - & - \\
\hline Acanthognathus ocellatus Mayr, 1887 & - & - & - & 1 \\
\hline Acanthognathus rudis Brown \& Kempf, 1969 & - & 1 & 3 & - \\
\hline Strumigenys appretiata (Borgmeier, 1954) & - & 1 & - & 1 \\
\hline Strumigenys crassicornis Mayr, 1887 & 8 & 1 & 6 & 32 \\
\hline Strumigenys denticulata Mayr, 1887 & 48 & 48 & 41 & 23 \\
\hline Strumigenys elongata Roger, 1863 & - & 5 & - & - \\
\hline Strumigenys schmalzi Emery, 1906 & 2 & - & 2 & 4 \\
\hline Strumigenys sp.6 & 2 & 3 & 4 & 1 \\
\hline Strumigenys sp.12 & 12 & - & 3 & 6 \\
\hline Strumigenys sp.14 & - & - & - & 2 \\
\hline Strumigenys sp.15 & 1 & 7 & 10 & - \\
\hline Strumigenys louisianae Roger, 1863 & - & 3 & 4 & 7 \\
\hline Adelomyrmex sp.1 & - & - & - & 2 \\
\hline Hylomyrma balzani (Emery, 1894) & - & - & - & 1 \\
\hline Hylomyrma reitteri (Mayr, 1887) & 3 & 33 & 37 & 29 \\
\hline Phalacromyrmex fugax Kempf, 1960 & - & - & 1 & - \\
\hline Pheidole sp.4 & 1 & - & - & - \\
\hline Pheidole sp.5 & - & - & - & 8 \\
\hline Pheidole sp.6 & - & - & - & 3 \\
\hline Pheidole sp.7 & 45 & 48 & 45 & 44 \\
\hline Pheidole sp.8 & - & - & - & 1 \\
\hline Pheidole sp.9 & 1 & - & 2 & - \\
\hline Pheidole sp.12 & - & 7 & - & - \\
\hline Pheidole sp.13 & 1 & 8 & 3 & 32 \\
\hline Pheidole sp.14 & - & - & 3 & 2 \\
\hline Pheidole sp.15 & 1 & - & - & 29 \\
\hline Pheidole sp.16 & 2 & 2 & 19 & - \\
\hline Pheidole sp.17 & - & - & - & 1 \\
\hline Pheidole sp.18 & - & 2 & - & - \\
\hline Pheidole sp.19 & 1 & - & 1 & - \\
\hline Pheidole sp.20 & 7 & 7 & 6 & 1 \\
\hline Pheidole sp.21 & - & 11 & 25 & 2 \\
\hline Pheidole sp.22 & 3 & 3 & - & - \\
\hline Pheidole sp.23 & 2 & 3 & 12 & - \\
\hline Pheidole sp.24 & 4 & - & - & - \\
\hline Pheidole sp.26 & - & - & - & 1 \\
\hline Pheidole sp.27 & 2 & 1 & - & - \\
\hline Pheidole sp.28 & 21 & 12 & 14 & 19 \\
\hline Pheidole sp.30 & 3 & 10 & 5 & 4 \\
\hline
\end{tabular}




\begin{tabular}{|c|c|c|c|c|}
\hline Subfamily/species & Eg4 & Es16 & Eg31 & SF \\
\hline Pheidole sp.31 & 12 & 9 & - & 3 \\
\hline Pheidole sp.32 & - & - & - & 2 \\
\hline Pheidole sp.33 & - & - & 2 & 4 \\
\hline Pheidole sp.36 & - & - & 2 & 1 \\
\hline Pheidole sp.39 & - & 2 & 14 & 30 \\
\hline Pheidole sp.43 & - & - & 2 & - \\
\hline Carebara sp.1 & - & - & - & 1 \\
\hline Megalomyrmex goeldii Forel, 1912 & - & 1 & - & - \\
\hline Megalomyrmex iheringi Forel, 1911 & - & 4 & 4 & 6 \\
\hline Monomorium pharaonis (Linnaeus, 1758) & - & - & 1 & - \\
\hline Oxyepoecus venezyi (Forel, 1907) & - & - & - & 1 \\
\hline Oxyероесus sp. 2 & - & 6 & 6 & 4 \\
\hline Solenopsis saevissima (F. Smith, 1855) & 1 & - & - & - \\
\hline Solenopsis wasmannii Emery, 1894 & 20 & 13 & 12 & 33 \\
\hline Solenopsis sp.2 & 42 & 44 & 35 & 48 \\
\hline Solenopsis sp.4 & 39 & 20 & 25 & 41 \\
\hline Lachnomyrmex plaumanni Borgmeier, 1957 & 4 & 17 & 9 & 14 \\
\hline Lachnomyrmex sp.1 & - & 1 & 1 & - \\
\hline \multicolumn{5}{|l|}{ Ponerinae } \\
\hline Anochetus altisquamis Mayr, 1887 & - & 1 & 2 & 6 \\
\hline Hypoponera sp.1 & 24 & 34 & 30 & 42 \\
\hline Hypoponera sp.3 & 1 & 1 & - & 6 \\
\hline Hypoponera sp.4 & 20 & 4 & 16 & 4 \\
\hline Hypoponera sp.5 & 1 & - & 1 & 10 \\
\hline Hypoponera sp.6 & - & 3 & 10 & 12 \\
\hline Hypoponera sp.7 & 5 & 1 & 2 & 2 \\
\hline Hypoponera sp.8 & 33 & 41 & 48 & 35 \\
\hline Hypoponera sp.9 & 9 & 1 & 7 & 13 \\
\hline Hypoponera sp.10 & - & - & - & 1 \\
\hline Hypoponera sp.11 & - & 1 & 4 & 4 \\
\hline Hypoponera sp.12 & - & - & 1 & 1 \\
\hline Leptogenys sp. 2 & - & - & - & 2 \\
\hline Odontomachus affinis Guérin, 1844 & 1 & 2 & 1 & 1 \\
\hline Odontomachus meinerti Forel, 1905 & - & - & - & 2 \\
\hline Pachycondyla bucki (Borgmeier, 1927) & - & - & 1 & - \\
\hline Pachycondyla constricta (Mayr, 1884) & 5 & 15 & 9 & 17 \\
\hline Pachycondyla crenata (Roger, 1961) & - & 1 & - & - \\
\hline Pachycondyla ferruginea (F. Smith, 1858) & 2 & - & 2 & - \\
\hline Pachycondyla harpax (Fabricius, 1804) & 2 & 3 & 2 & 1 \\
\hline Pachycondyla striata Fr. Smith, 1858 & - & 1 & - & - \\
\hline Pachycondyla sp.9 & - & 1 & - & - \\
\hline Pachycondyla sp.10 & 2 & - & - & - \\
\hline Typhlomyrmex sp.2 & - & - & 1 & 4 \\
\hline \multicolumn{5}{|l|}{ Proceratiinae } \\
\hline Discothyrea neotropica Bruch, 1919 & 5 & - & - & - \\
\hline Discothyrea sexarticulata Borgmeier, 1954 & - & 1 & - & 2 \\
\hline \multicolumn{5}{|l|}{ Pseudomyrmecinae } \\
\hline Pseudomyrmex gracilis (Fabricius, 1804) & 1 & 1 & 1 & - \\
\hline Pseudomyrmex pallidus (F. Smith, 1855) & - & - & 2 & - \\
\hline Number of species & 61 & 76 & 79 & 87 \\
\hline
\end{tabular}




\section{Discussion}

Although the small spatial scale of plantations and secondgrowth forest in our study area did not enable us to implement a robust replicated design, our results suggest that the leaf-litter ant fauna responds to the age of regenerating Eucalyptus plantations. In general, the number of species present in Eucalyptus plantations varied according to the understory structure, being markedly different in the youngest Eucalyptus plantation. Despite the increase in average ant species richness at the sample level along the regeneration gradient, the secondary forest maintained the highest species richness (Soares et al. 1998, Schnell et al. 2003). The capacity of more of ant species to colonize Eucalyptus plantations is probably limited by the shortage of native plant species (Majer et al. 1984) and micro-habitats, such as leaf-litter accumulated around fallen logs (Andrew et al. 2000).

In our study, the site with assemblage most like those of the secondary forest reference site was the older Eucalyptus plantation (the sites share approximately 50\% of the ant fauna). Although eucalipt plantations are intended primarily for the purpose of timber production, their ability to restore invertebrates biodiversity in modified landscapes has been evaluated in Australia (Schnell et al. 2003) and South America (Soares et al. 1998, Marinho et al. 2002, Fonseca \& Diehl 2004, Barlow et al. 2007a, b). Strong evidences of a successional change in ant communities in response to tree growth within Eucalyptus plantations has been described (Schnell et al. 2003). Soares et al. (1998) also compared the ant fauna of a eucalypt plantation with that of a native secondary regrowth forest in Brazil and found that the secondary forest support a greater number of ant species than the eucalypt plantation. However, some studies have found different responses of the ant fauna to eucalipt plantation ages. For example, the richness of epigaeic ant species was not related to age of eucalipt forests planted in sandbanks (Fonseca \& Diehl 2004), and Marinho et al. (2002) demonstrated that most of the species found in native vegetation occur also in the eucalypt plantations.

We did not find a relationship between species richness and leaf-litter depth (used as a surrogate of resource availability for the leaf-litter ant fauna) in the Eucalyptus or secondary forest. Although the density of litter-dwelling ants increases with litter biomass (Kaspari 1996a, McGlynn et al. 2007), litter biomass can only account for a fraction of the variance in ant densities or ant species richness (Kaspari 1996b, McGlyn et al. 2009). In the litter, frequent disturbances, varying in scale from branch falls to stronger rainfalls, obscures the resource-density correlation (Kaspari 1996b). Further, studies on patch dynamics of ant colonies have showed that colonies may migrate on a weekly or monthly basis in response to predation (Kaspari 1996b).

It is well known that the physical and chemical structure of leaf-litter formed by Eucalyptus trees decrease decomposition by micro-organisms (Majer \& Recher 1999), affecting the structure and dynamics of litter formation (Schneider 2003). Because the resource base of ants is supported by the detrital food web (Kaspari \& Yanoviak 2008), we may expect a weaker correlative relationship between leaf-litter depth and ant species richness in Eucalyptus plantations.

Our data show the presence mainly of generalist species and of few species specialized (Brown Jr. 2000) in Eucalyptus plantations, such as specialized predators or hypogaeic nomadic species of Ecitoninae. The simplified habitats created by management practices in commercial forests often favours generalist species and decrease the diversity of forest specialists such as litter-dwelling cryptic species (Andersen et al. 2009), which require a complex litter layer. Generalist ants are more likely to find sufficient resources within a patch, as compared to specialist species, which have limited mechanisms of dispersal and prefer locally limited resources (Pacheco et al. 2009).
It is interesting to mention the presence of the rarely collected Phalacromyrmex fugax Kempf in the 31-years-old Eucalyptus site; until now, this species was known only from a few individuals in museum collections

In sum, our results indicate that the ant species richness and composition changed along the regeneration gradient of Eucalyptus forests and in comparison to secondary Atlantic Forest. However, Eucalyptus and secondary forests are unlikely to conserve most primary forest species, such as groups of specialist predators and nomadic species, which show specialized biology. Furthermore, this study serves to highlight the potential importance of native understory vegetation for the conservation of leaf-litter ants. Further, our study suggest that examine the invertebrate ecological responses to disturbance regimes is vital if research is to inform and improve sustainable forest management practices.

\section{Acknowledgements}

We would like to thank the Fundação de Amparo ao Ensino e Pesquisa (FAEP/UMC) for the scholarship granted to the first author.

\section{References}

AGOSTI, D. \& ALONSO, L.E. 2000. The ALL Protocol: a standard protocol for the collection of ground-dwelling ants. In Measuring and monitoring biological diversity: standard methods for ground living ants (D. Agosti, J.D. Majer, L.E. Alonso \& T.R. Schultz, eds.). Smithsonian Institution Press, Washington, DC., p.204-206.

ANDERSEN, A.N., PENMAN, T.D., DEBAS, N. \& HOUADRIA, M. 2009. Ant community responses to experimental fire and logging in a eucalypt forest of south-eastern Australia. For. Ecol. Manag. 258:188-197.

ANDREW, N., RODGERSON, L. \& YORK, A. 2000. Frequent fuel-reduction burning: the role of logs and associated leaf litter in the conservation of ant biodiversity. Austral Ecol. 25(1):99-107.

BARLOW, J., GARDNER, T.A., ARAUJO, I.S., ÁVILA-PIRES, T.C., BONALDO, A.B., COSTA, J.E., ESPOSITO, M.C., FERREIRA, L.V., HAWES, J., HERNANDEZ, M.I.M., HOOOGMOED, M.S., LEITE, R.N., LO-MAN-HUNG, N.F., MALCOLM, J.R., MARTINS, M.B., MESTRE, L.A.M., MIRANDA-SANTOS, R., NUNES-GUTJAHR, A.L., OVERAL, W.L., PARRY, L., PETERS, S.L., RIBEIRO-JUNIOR, M.A., SILVA, M.N.F., SILVA MOTTA, C. \& PERES,C.A. 2007a. Quantifying the biodiversity value of tropical primary, secondary, and plantation forests. PNAS 104(47):18555-18560.

BARLOW, J., OVERAL, W.L., ARAUJO, I.S., GARDNER, T.A. \& PERES, C.A. $2007 \mathrm{~b}$. The value of primary, secondary and plantation forests for fruit-feeding butterflies in the Brazilian Amazon. J. Appl. Ecol. 44(5):1001-1012.

BESTELMEYER, B.T., AGOSTI, D., ALONSO, L.E., BRANDÃO, C.R.F., BROWN JR., W.L., DELABIE, J.H.C. \& SILVESTRE, R. 2000. Field techniques for the study of ground-dwelling ants. In Measuring and monitoring biological diversity: standard methods for ground living ants (D. Agosti, J.D. Majer, L.E. Alonso \& T. Schultz, eds.), Smithsonian Institution Press, Washington, DC., p.122-144.

BOLTON, B., ALPERT, G., WARD, P.S. \& NASKRECKI, P. 2006. Bolton's catalogue of ants of the world. Harvard University Press, Cambridge, MA., p.1758-2005.

BROWN Jr, W.L. 2000. Diversity of ants. In Measuring and monitoring biological diversity: standard methods for ground living ants (D. Agosti, J.D. Majer, L.E. Alonso \& T.R. Schultz, eds.). Smithsonian Institution Press, Washington, DC., p.45-79.

CARNAVAL, A.C., HICKERSON, M.J., HADDAD, C.F.B., RODRIGUES, M.T. \& MORITZ, C. 2009. Stability predicts genetic diversity in the Brazilian Atlantic Forest Hotspot. Science 323(5915):785-789.

COLWELL, R.K. 2005. EstimateS: statistical estimation of species richness and shared species from samples, version 7.5.2.: http://purl.oclc.org/ estimates (accessed 03/02/2008).

CRAWLEY, M.J. 2002. Statistical computing: an introduction to data analysis using S-Plus. John Wiley, New York. 
DUNN, R.R. 2004. Managing the tropical landscape: a comparison of the effects of logging and forest conversion to agriculture on ants, birds, and lepidoptera. For. Ecol.Manag. 191(1-3):215-224.

DURAN, S.M. \& KATTAN, G.H. 2005. A test of the utility of exotic tree plantations for understory birds and food resources in the Colombian Andes. Biotropica 37(1):129-135.

FOLGARAIT, P.J. 1998. Ant biodiversity and its relationship to ecosystem functioning: a review. Biodivers. Conserv. 7(9):1221-1244.

FONSECA, R.C. \& DIEHL, E. 2004. Riqueza de formigas (Hymenoptera, Formicidae) epigéicas em povoamentos de Eucalyptus spp. (Myrtaceae) de diferentes idades no Rio Grande do Sul, Brasil. Rev. Brasil. Entomol. 48(1):95-100

GARDNER, T.A., BARLOW, J. \& PERES, C.A. 2007. Paradox, presumption and pitfalls in conservation biology: the importance of habitat change for amphibians and reptiles. Biol. Conserv. 138(1-2):166-179.

GARDNER, T.A., HERNÁNDEZ, M.I.M., BARLOW, J. \& PERES, C.A. 2008. Understanding the biodiversity consequences of habitat change: the value of secondary and plantation forests for neotropical dung beetles. J. Appl. Ecol. 45(3):883-893.

GIRAUDOUX, P. 2010. pgirmess: Data analysis in ecology. R package version 1.4.5.: http://CRAN.R-project.org/package=pgirmess (accessed 06/04/2009).

GOTELLI, N.J. \& COLWELL, R.K. 2001. Quantifying biodiversity: procedures and pitfalls in the measurement and comparison of species richness. Ecol. Lett. 4(4):379-391.

HÖLLDOBLER, B. \& WILSON, E.O. 1990. The ants. Belknap Press, Cambridge, Massachussets, 732p.

KANOWSKI, J., CATTERALL, C.P. \& WARDELL-JOHNSON, G.W. 2005. Consequences of broadscale timber plantations for biodiversity in cleared rainforest landscapes of tropical and subtropical Australia. For. Ecol. Manag. 208(1-3):359-372.

KASPARI, M. \& YANOVIAK, S.P. 2008. Biogeography of litter depth in tropical forests: evaluating the phosphorus growth rate hypothesis. Funct. Ecol. 22(5):919-923.

KASPARI, M. 1996a. Litter ant patchiness at the 1-m² scale: disturbance dynamics in three Neotropical forests. Oecologia 107(2):265-273.

KASPARI, M. 1996b. Testing resource based models of patchiness in four Neotropical litter ant assemblages. Oikos 76(3):443-454, 1996.

KRONKA, F.J.N. (coord.). 2005. inventário florestal da vegetação natural do Estado de São Paulo. Instituto Florestal, São Paulo.

LASSAU, S.A. \& HOCHULI, D.F. 2004. Effects of habitat complexity on ant assemblages. Ecography 27(2):157-164.

LASSAU, S.A., HOCHULI, D.F., CASSIS, G. \& REID, C.A.M. 2005. Effects of habitat complexity on forest beetle diversity: do functional groups respond consistently? Divers. Distrib. 11(1):73-82.

LAURANCE, W.F. 2009. Conserving the hottest of the hotspots. Biol. Conserv. 142(6):1137.

LIMA, W.P. 1993. Impacto Ambiental do Eucalipto. $2^{\text {nd }}$ ed. Editora da Universidade de São Paulo, São Paulo, 301p.

MACHADO, R.B. \& LAMAS, I.R. 1996. Birds species associated to an Eucalyptus plantation in the country of Antonio Dias, Minas Gerais. Ararajuba 4:15-22.

MAJER, J.D. \& RECHER, H.F. 1999. Are eucalypts Brazil's friend or foe? An Entomological viewpoint. An.Soc. Entomol. Bras. 28(2):185-200.

MAJER, J.D., DAY, J.E., KABAY, E.D. \& PERRIMAN, W.S. 1984. Recolonization by ants in bauxite mines rehabilitated by a number of different methods. J. Appl. Ecol. 21(1):355-375.

MARINHO, S.G., ZANETTI, R., DELABIE, J.H.C., SCHLINDWEIN, M.N. \& RAMOS, L.S. 2002. Diversidade de formigas (Hymenoptera: Formicidae) da serapilheira em eucaliptais (Myrtaceae) e área de cerrado de Minas Gerais. Neotr. Entomol. 31(2):187-195.

MARTINI, A.M.Z., FIASCHI, P., AMORIM, A.M. \& PAIXÃO, J.L. 2007. A hot-point within a hotspot: a high diversity site in Brazil's Atlantic Forest. Biodivers. Conserv. 16:3111-3128.

MCGEOCH, M.A. \& CHOWN, S.L. 1998. Scaling up the value of bioindicators. Trends in Ecol. Evol. 13(2):46-47.
MCGLYNN, T.P., FAWCETT, R.M. \& CLARK, D.A. 2009. Litter biomass and nutrient determinants of ant density, nest size, and growth in a Costa Rica Tropical Wet Forest. Biotropica 41(3):234-240.

MCGLYNN, T.P., SALINAS, D.J., DUNN, R.R., WOOD, T.E., LAWRANCE, D. \& CLARK, D.B. 2007. Phosphorus limits tropical rain forest litter fauna. Biotropica 39(1):50-53.

MCKEY, D., ROSTAIN, S.; IRIARTE, J., GLASER, B., BIRK, J.J., HOLST, I. \& RENARD, D. 2010.Pre-columbian agricultural landscapes, ecosystem engineers, and self-organized patchiness in Amazonia. PNAS 107(17):7823-7828.

METZGER, J.P., MARTENSEN, A.C., DIXO, M., BERNACCI, L.C., RIBEIRO, M.C., TEIXEIRA, A.M.G. \& PARDINI, R. 2009. Time-lag in biological responses to landscape changes in a highly dynamic Atlantic forest region. Biol. Conserv. 142(6):1166-1177.

MITRA, S.S. \& SHELDON, F.H. 1993. Use of an exotic plantation by Bornean lowland forest birds. Auk 110(3):529-540.

MYERS, N., MITTERMEIER, R.A., MITTERMEIER, C.G., FONSECA, G.A.B. \& KENT, J. 2000. Biodiversity hotspots for conservation priorities. Nature 403(6772):853-858.

OKSANEN, J., KINDT, R., LEGENDRE, P., O'HARA, B. \& STEVENS, M.H.H. 2009. Vegan: Community Ecology Package. R package version 1.15-1.: http://cran.r-project.org/, http://r-forge.r-project.org/projects/ vegan/ (accessed 02/03/2008).

PACHECO, R., SILVA, R.R., MORINI, M.S.C. \& BRANDÃO, C.R.F. 2009. A comparison of the leaf-litter ant fauna in a secondary Atlantic Forest with an adjacent pine plantation in southeastern Brazil. Neotrop. Entomol. 38(1):55-65.

PINKUS-RENDÓN, M.A., LEÓN-CORTÉS, M.A. \& IBARRA-NÚÑEZ, G. 2006. Spider diversity in a tropical habitat gradient in Chiapas, Mexico. Divers. Distrib. 12(3):61-69.

RIBEIRO, M.C., METZGER, J.P., MARTENSEN, A.C., PONZONI, F. \& HIROTA, M.M. 2009. Brazilian Atlantic forest: how much is left and how is the remaining forest distributed? Implications for conservation. Biol. Conserv. 142(6):1141-1153.

SOCIEDADE BRASILEIRA DE SILVICULTURA - SBS. 2006. http://www. sbs.org.br/ (accessed 02/02/2006).

SCHNEIDER, M.F. 2003. Conseqüências da acumulação de folhas secas na plantação de eucalipto em Zitundo, Distrito de Matutuíne. Bol. Invest. Flor. 3:37-42.

SCHNELL, M.R., PIK, A.J. \& DANGERFIELD, J.M. 2003. Ant community succession within eucalypt plantations on used pasture and implications for taxonomic sufficiency in biomonitoring. Austral Ecol. 28(5):553-565.

SOARES, S.M., MARINHO, C.G.S. \& DELLA LUCIA, T.M.C. 1998. Riqueza de espécies de formigas edáficas em plantação de eucalipto e em mata secundária nativa. Rev. Brasil. Zool. 15(4):889-898.

SOS MATA ATLÂNTICA 1998. Evolução dos remanescentes florestais e ecossistemas associados do domínio Mata Atlântica no período 19901995. Fundação SOS Mata Atlântica; INPE, São Paulo.

STALLINGS, J.R. 1991. The importance of understorey on wildlife in a Brazilian Eucalyptus plantation. Rev. Brasil. Zool. 7(1-4):267-276.

SUMMERVILLE, K.S. \& CRIST, T.O. 2002. Effects of timber harvest on forest Lepidoptera: community, guild, and species responses. Ecol. Appl. 12(3):820-835.

TEWS, J., BROSE, U., GRIMM, V., TIELBÖRGER, K., WICHMANN, M.C., SCHWAGER, M. \& JELTSCH, F. 2004. Animal species diversity driven by habitat heterogeneity/diversity: the importance of keystone structures. J. Biogeog. 31(1):79-92.

UEHARA-PRADO, M., FERNANDES, J.O., BELLO, A.M., MACHADO, G., SANTOS, A.J., VAZ-DE-MELO, F.Z. \& FREITAS, A.V.L. 2009. Selecting terrestrial arthropods as indicators of small-scale disturbance: a first approach in the Brazilian Atlantic forest. Biol. Conserv. 142(6):1220-1228.

UNDERWOOD, E.C. \& FISHER, B.L. 2006. The role of ants in conservation monitoring: if, when, and how. Biol. Conserv. 132(2):166-182.

WILLIS, E.O. 2003. Birds of a Eucalyptus woodlot in interior São Paulo. Braz. J. Biol. 63(1):141-158.

WRIGHT, S.J. \& MULLER-LANDAU, S.J. 2006. The future of tropical forest species. Biotropica 38(4):287-301. 